BMC

Public Health

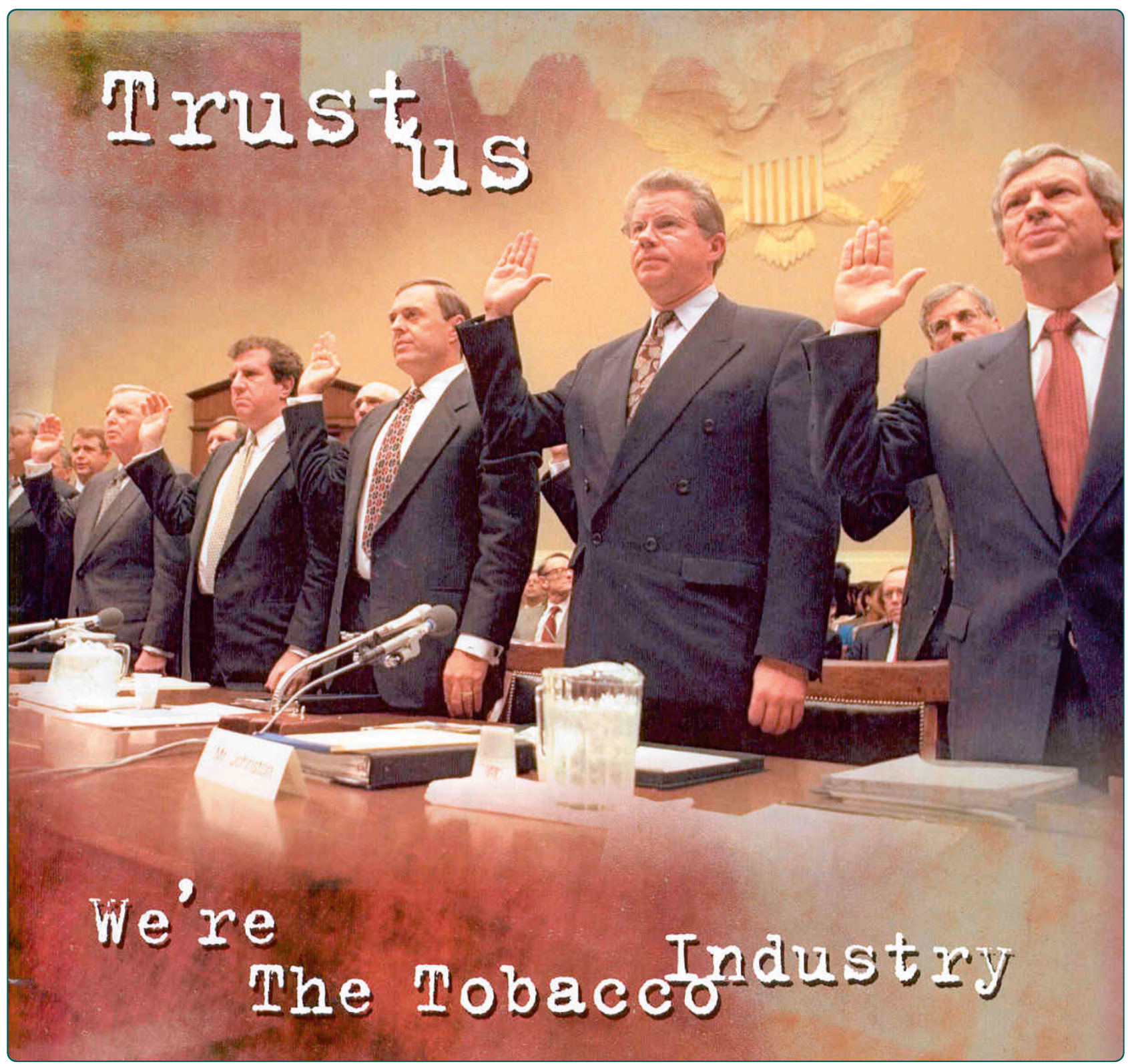

The so-called "Spanish model" - Tobacco industry strategies and its impact in Europe and Latin America

Schneider et al. 


\title{
The so-called "Spanish model" - Tobacco industry strategies and its impact in Europe and Latin America
}

\author{
Nick K Schneider ${ }^{1}$, Ernesto M Sebrié ${ }^{2}$ and Esteve Fernández ${ }^{3,4^{*}}$
}

\begin{abstract}
Background: To demonstrate the tobacco industry rationale behind the "Spanish model" on non-smokers' protection in hospitality venues and the impact it had on some European and Latin American countries between 2006 and 2011.

Methods: Tobacco industry documents research triangulated against news and media reports.

Results: As an alternative to the successful implementation of $100 \%$ smoke-free policies, several European and Latin American countries introduced partial smoking bans based on the so-called "Spanish model", a legal framework widely advocated by parts of the hospitality industry with striking similarities to "accommodation programmes" promoted by the tobacco industry in the late 1990s. These developments started with the implementation of the Spanish tobacco control law (Ley 28/2005) in 2006 and have increased since then.
\end{abstract}

Conclusion: The Spanish experience demonstrates that partial smoking bans often resemble tobacco industry strategies and are used to spread a failed approach on international level. Researchers, advocates and policy makers should be aware of this ineffective policy.

\section{Background}

The World Health Organization Framework Convention on Tobacco Control (WHO FCTC), which was ratified by 174 parties (as of September 2011) including Spain, calls inter alia for the implementation of comprehensive smokefree policies [1]. In January 2006 the Spanish government enacted its former "tobacco control law" (Ley 28/2005), which implemented many measures covered by the FCTC (restrictions on tobacco sales, comprehensive advertising bans, smoking bans at workplaces, etc.), but also allowed owners of "small" hospitality venues (smaller than $100 \mathrm{~m}^{2}$ ) to choose whether smoking should be allowed in their venues or not [2]. Between 2006 and 2010, tobacco taxes have risen, overt promotion has decreased, overall exposure to second hand smoke has declined, and access to cessation advice and services has increased. Muggli et al. thoroughly described the genesis of this legislation and Granero et

\footnotetext{
* Correspondence: efernandez@iconcologia.net

${ }^{3}$ Tobacco Control Unit, Cancer Prevention \& Control Programme, Institut

Català d'Oncologia-IDIBELL, L'Hospitalet de Llobregat, Barcelona, Spain

Full list of author information is available at the end of the article
}

al. showed the involvement of different actors, especially those favouring Tobacco Industry interests $[3,4]$. In this case study we restrict our focus to the so-called "Spanish model" of non-smokers' protection in hospitality venues and its similarities to Philip Morris' (PM) accommodation programmes and demonstrate that thereafter (2006-2011) some European and Latin American countries also introduced similar ineffective legislation.

\section{Methods}

Between October 2009 and February 2010 we searched previously secret internal tobacco industry documents available through litigation in the United States in the electronic Legacy Tobacco Documents Library at the University of California at San Francisco (http://legacy. library.ucsf.edu/)[5]. We used the search terms "Spain", "accommodation", "courtesy of choice" and "traditional hospitality" and triangulated them against online articles of major newspapers using Google (http://www.google. com) and tobacco industry publications using the online database of the Tobacco Journal International (http:// www.tobaccojournal.com). In total 3.950 documents

\section{() Biomed Central}


included the words "Spain" and "accommodation". After screening the documents the search could be narrowed down to specific accommodation programmes. The number of documents was thus reduced to 401 by adding the specific search terms "Courtesy of Choice" and "Traditional Hospitality" (see table 1). After screening all documents for relevance and discarding duplicates 101 documents were included in the analysis. The key documents identified are summarized in table 2 . No relevant additional documents were identified with a search in Spanish (search terms "España" and "acomodación", "hospitalidad" or "convivencia"). The documents were systematically analyzed using a Boolean search [5]. To explore the impact of the "Spanish model" on other countries the search was conducted using the terms "Spanish model" and "hospitality" in English, Spanish and German. Only articles from online newspapers, hospitality and tobacco industry publications referring to tobacco use in hospitality venues were included. 50 relevant news articles were identified and analysed. In addition the information retrieved was triangulated against the legislation of the countries identified in media articles. The relevant documents that finally contributed to the analysis are cited in the final reference list.

\section{Results}

Tobacco industry's accommodation programmes

Aware of the increasing trend towards smoking restrictions and bans in public venues in the early to mid 1990s, PM introduced an international accommodation campaign as a tactical tool to create goodwill amongst legislators and prevent smoking bans [6]. The strategy was coordinated by the Worldwide Regulatory Affairs department with the objective to "initiate, develop and assist with the implementation of worldwide programs that encourage self-regulation and recognize the benefits of using ventilation effectively to facilitate reasonable accommodation and preserve the social acceptability of smoking" [7]. It used a three-tier-approach: 1) "Courtesy of Choice", to establish smoking and non-smoking rooms, using ventilation to accomplish separation; 2) "Traditional Hospitality", to "enhance the comfort for all customers in small restaurants, cafes, bars and taverns [...] without separating into smoking and non-smoking areas."; and 3) "A Smoking Place", as a smoking lounge concept for large public spaces, e.g. in Spanish airports
[8], to demonstrate the "compatibility of indoor environmental quality and accommodating smoking" [7].

Although the programmes were run by the International Hotels \& Restaurants' Association (IH\&RA) in collaboration with public relations firms and ventilation experts, the oversight, strategic planning and funding came from PM's Worldwide Regulatory Affairs department [6]. Since its rollout in 1995, with 460 sites in 9 countries and costs of roughly US\$ 1 million, the international accommodation programme expanded considerably, operating in 8.357 sites in 47 countries and costing US\$ 15 million in 1999 [6,9] $]^{9}$. The ultimate goal of this global programme was to prevent smoking bans and restrictions by creating a reasonable and viable alternative to smoking bans $[6,10]$. To maximise the impact on legislators on regional, national and European level, key venues were chosen for the programmes, such as the restaurants of the Bilbao Guggenheim Museum and the Bilbao City Auditorium "Palacio Euskalduna" in Spain, as examples for "Traditional Hospitality" [11], as well as the restaurants of the Belgian and Dutch national Parliaments, the Council of Europe (3 locations), European Court of Human Rights (2 locations) and the European Parliament in Strasbourg, as examples of "Courtesy of Choice" [5].

\section{Birth of the "Spanish Model"}

Spain was involved in the programme since 1996 [10] and was one of only 5 countries to pilot "Traditional Hospitality" in 1999, along with Belgium, the Czech Republic, Italy and the Netherlands [6]. In 1999 the public relations agency J.A. Llorente \& O. Cuenca was contracted by PM to run the "Traditional Hospitality" programme in Spain and "Courtesy of Choice" in Latin America [12,13]. According to PM the agency's "presence in Europe adds value to the program since they will be well positioned to transfer knowledge across the two regions and share the many worthy Latin American initiatives" [13]. In Spain the agency's role also included "establishing appropiate relations with the Spanish Restaurant Association,(FER), in order to implement the programme sponsored by the IHERA, with the "FER" acting as cosponsors" [13]. PM also commissioned an economic study which suggested that a proposed bill would cause a 7\% decline in Spanish restaurant revenues and large declines in hospitality industry profits [5]. Besides

Table 1 Search terms and number of identified tobacco industry documents

\begin{tabular}{ll}
\hline Search terms used in the Legacy Tobacco Documents Library & Number of documents \\
\hline Spain AND accommodation & 3950 \\
\hline Spain AND accommodation AND Courtesy of Choice & 979 \\
\hline Spain AND accommodation AND Courtesy of Choice AND Traditional Hospitality & 401 \\
\hline Number of documents after screening for relevance and discarding duplicates & 101 \\
\hline
\end{tabular}


Table 2 Summary and nature of key documents used in the analysis of the tobacco industry strategies

\begin{tabular}{|c|c|c|c|}
\hline Document & Author & Date & Contents \\
\hline \multicolumn{4}{|l|}{ Global strategy } \\
\hline $\begin{array}{l}\text { Worldwide Strategy and Plan to Accommodate } \\
\text { the Diverse Expectations Regarding Smoking in } \\
\text { Strategic Public Settings and the Role of } \\
\text { Ventilation [10]. }\end{array}$ & $\begin{array}{l}\text { Prepared in coordination of: } \\
\text {-PM International } \\
\text {-PM USA } \\
\text {-Corporate Affairs } \\
\text {-Worldwide Operations and } \\
\text { Technology } \\
\text {-Worldwide Regulatory Affairs }\end{array}$ & $\begin{array}{l}\text { February } \\
1998\end{array}$ & $\begin{array}{l}\text { Internal presentation describing the worldwide } \\
\text { strategy and plan behind the accommodations } \\
\text { programs, including a situation analysis, } \\
\text { definition of a common goal, several objectives, } \\
\text { and specific strategies to achieve them. }\end{array}$ \\
\hline Accommodation and Smoking restrictions [7] & Worldwide Regulatory Affairs & $\begin{array}{l}\text { October } \\
1998\end{array}$ & $\begin{array}{l}\text { Draft plan for } 1999 \text { outlining different strategies } \\
\text { to solve the issue of: "Unreasonable restrictions } \\
\text { on the use of our tobacco products in public } \\
\text { venues". The document highlights the } \\
\text { objectives identified, suggested strategies and } \\
\text { needed. The strategies include inter alia the } \\
\text { following international accommodation } \\
\text { programs: "Courtesy of Choice", "Traditional } \\
\text { Hospitality" and "A Smoking Place". }\end{array}$ \\
\hline International Accommodations Programs [6] & $\begin{array}{l}\text { Goldberg H., Vice President } \\
\text { Environmental Policy, Worldwide } \\
\text { Regulatory Affairs, Philip Morris } \\
\text { International }\end{array}$ & July 1999 & $\begin{array}{l}\text { Internal report and background document } \\
\text { which internally demonstrated that the } \\
\text { "International Accommodation Program is very } \\
\text { effective"s. The document presents the logic of } \\
\text { accommodation, the structure and costs of } \\
\text { "Courtesy of Choice" and "Traditional Hospitality", } \\
\text { their status and future plans, as well as the } \\
\text { barriers of and alternatives to the programs. }\end{array}$ \\
\hline Accommodation Programs - where next? [9] & $\begin{array}{l}\text { Goldberg H., Vice President } \\
\text { Environmental Policy, Worldwide } \\
\text { Regulatory Affairs, Philip Morris } \\
\text { International }\end{array}$ & $\begin{array}{l}\text { January } \\
2000\end{array}$ & $\begin{array}{l}\text { Slides and speaking notes highlighting the } \\
\text { growth of the program between } 1995 \text { and 2000, } \\
\text { including number of participating outlets, } \\
\text { countries, costs and regulatory benefits in } \\
\text { different markets. }\end{array}$ \\
\hline \multicolumn{4}{|l|}{ Implementation in Spain and Latin America } \\
\hline Consulting Services Agreement [12] & $\begin{array}{l}\text { F. J. Braña for Philip Morris Spain } \\
\text { and J. Areitio and J.A. Llorente for } \\
\text { J.A. Llorente \& O. Cuenca }\end{array}$ & May 1999 & $\begin{array}{l}\text { Consulting services agreements between PM } \\
\text { Spain and the public relations agency J.A. } \\
\text { Llorente \& O. Cuenca with regard to the } \\
\text { management and coordination of among others } \\
\text { the "Traditional Hospitality" programme the } \\
\text { "FER" (Federación Española de Restaurantes. } \\
\text { Cafeterias y Bares) and local hostelry associations } \\
\text { with "ATECYR" (Asociación Técnica Española de } \\
\text { Climatización y Refrigeración) }\end{array}$ \\
\hline $\begin{array}{l}\text { Convivencia en Armonía - New Regional Agency } \\
\text { [13] }\end{array}$ & $\begin{array}{l}\text { Jacqueline P.Hasty, Supervisor, } \\
\text { Communications, Philip Morris } \\
\text { International }\end{array}$ & $\begin{array}{l}\text { December } \\
1999\end{array}$ & $\begin{array}{l}\text { Inter-office correspondence informing about the } \\
\text { selection and engagement of J.A. Llorente \& O. } \\
\text { Cuenca as the new public relations agency to } \\
\text { coordinate the Convivencia en Armonia/Cortesía } \\
\text { de Elejir programs in Latin America }\end{array}$ \\
\hline
\end{tabular}

extensive work by national and international tobacco control advocates and researchers [3,4], the pro-tobacco lobby not only did succeed in "proving the case" and passing a "reasonable legislation" [6,7], but actually managed to lock measures resembling both accommodation programmes in national law: "Courtesy of Choice" for venues bigger than $100 \mathrm{~m}^{2}$ and "Traditional Hospitality" for smaller venues [2].

\section{Impact on European and Latin American countries}

We identified that since 2006 at least nine European and five Latin American countries introduced similar exceptions based on venue size, either on national or sub-national level (province) (Table 3).

Following the example of Spain, the exceptions for small venues and the focus on traditional hospitality had far-reaching consequences, especially in European countries with strong traditional values linked to tobacco use. Besides the German speaking countries and Croatia, all identified countries with partial bans were originally part of PM's accommodation programmes [6].

Germany was a special case, as PM deliberately decided not to run their programmes there. It reported that Germany had a well organized industry association 
Table 3 Size dependent partial smoking bans in Europe and Latin America and respective accommodation programs promoted by the tobacco industry

\begin{tabular}{|c|c|c|c|}
\hline \multirow[b]{2}{*}{ Measure } & \multirow{2}{*}{$\begin{array}{c}\text { Earlier existence of PM's } \\
\text { accommodation programmes }\end{array}$} & \multicolumn{2}{|c|}{ Partial smoking bans in hospitality venues (2006-2011) } \\
\hline & & $\begin{array}{l}\text { Designation of smoking } \\
\text { and non-smoking venues }\end{array}$ & $\begin{array}{l}\text { Separation into smoking and } \\
\text { non-smoking rooms }\end{array}$ \\
\hline $\begin{array}{l}\text { Corresponding } \\
\text { accommodation programme }\end{array}$ & & "Traditional Hospitality" & "Courtesy of Choice" \\
\hline \multicolumn{4}{|l|}{ Europe } \\
\hline $\begin{array}{l}\text { Spain } \\
(2006-2010)\end{array}$ & $\mathrm{TH}, \mathrm{CoC}$ & $\leq 100 \mathrm{~m}^{2}$ (accessible area) & $>100 \mathrm{~m}^{2}$ (accessible area) \\
\hline $\begin{array}{l}\text { Denmark } \\
\text { (since 2007) }\end{array}$ & $\mathrm{CoC}$ & $\leq 40 \mathrm{~m}^{2}$ & $>40 \mathrm{~m}^{2}$ \\
\hline $\begin{array}{l}\text { Austria } \\
\text { (since 2008) }\end{array}$ & - & $\begin{array}{c}\text { One room venues with }<50 \mathrm{~m}^{2} \\
\text { (or } 80 \mathrm{~m}^{2} \text { if separation legally } \\
\text { not feasible) }\end{array}$ & Venues with 2 or more rooms \\
\hline $\begin{array}{l}\text { German states } \\
\text { (Bavaria 2008-10; } \\
\text { all other states since 2008) }\end{array}$ & - & One room venues with $<75 \mathrm{~m}^{2}$ & Venues with 2 or more rooms \\
\hline $\begin{array}{l}\text { Greece } \\
(2009-2010)\end{array}$ & $\mathrm{CoC}$ & $\leq 70 \mathrm{~m}^{2}$ & $>70 \mathrm{~m}^{2}$ \\
\hline $\begin{array}{l}\text { Croatia } \\
\text { (since 2009) }\end{array}$ & - & $\leq 50 \mathrm{~m}^{2}$ & $>50 \mathrm{~m}^{2}$ \\
\hline $\begin{array}{l}\text { Switzerland } \\
\text { (since 2010) }\end{array}$ & - & $\begin{aligned} & \leq 80 \mathrm{~m}^{2} \\
& \text { (unless stronger Cantonal bans exist) }\end{aligned}$ & $\begin{array}{c}>80 \mathrm{~m}^{2} \\
\text { (unless stronger Cantonal bans } \\
\text { exist) }\end{array}$ \\
\hline $\begin{array}{l}\text { The Netherlands } \\
\text { (since 2010) }\end{array}$ & $\mathrm{TH}, \mathrm{CoC}$ & $\begin{array}{c}\leq>70 \mathrm{~m}^{2} \\
\text { (if only operated by owner) }\end{array}$ & $\begin{array}{l}\quad>70 \mathrm{~m}^{2} \\
\text { (or if not only owner operated) }\end{array}$ \\
\hline $\begin{array}{l}\text { Czech Republic } \\
\text { (since 2010) }\end{array}$ & $\mathrm{TH}, \mathrm{COC}$ & All venues & $\begin{array}{l}\text { Smoking rooms without } \\
\text { size specification }\end{array}$ \\
\hline \multicolumn{4}{|l|}{ Latin America } \\
\hline $\begin{array}{l}\text { Chile } \\
\text { (since 2006) }\end{array}$ & $\mathrm{CoC}$ & $\leq 100 \mathrm{~m}^{2}$ & $\begin{array}{l}\text { Bars, restaurants \& casinos } \\
\qquad>100 \mathrm{~m}^{2}\end{array}$ \\
\hline Bolivia (2007) & - & $\begin{array}{l}\text { Smoking venues (recreational venues for } \\
\text { older than } 18 \text { years old) }\end{array}$ & $\begin{array}{l}\text { Smoking rooms without } \\
\text { size specification }\end{array}$ \\
\hline $\begin{array}{l}\text { Province of Buenos Aires, } \\
\text { Argentina (2008) }\end{array}$ & $\mathrm{CoC}$ & $>400 \mathrm{~m}^{2}$ & $\begin{array}{l}\text { Smoking rooms without } \\
\text { size specification }\end{array}$ \\
\hline Mexico (2008) & $\mathrm{CoC}$ & - & $\begin{array}{l}\text { Smoking rooms without } \\
\text { size specification }\end{array}$ \\
\hline Nicaragua (2010) & - & - & $\begin{array}{l}\text { Smoking rooms without } \\
\text { size specification }\end{array}$ \\
\hline
\end{tabular}

CoC: Courtesy of Choice

TH: Traditional Hospitality

and PM's management was "not prepared to alienate the association" [6]. In 2007 and 2008 however, after the introduction of smoking bans in several German "Länder" (Federal States), tobacco industry lobbyists, the liberal party and the German hospitality industry association Deutscher Hotel- und Gaststättenverband (DeHoGa) advocated for the so-called "Spanish model" as an alternative to a $100 \%$ smokefree policy in oneroom venues: "In Spain they found a solution, which is fair to everyone"[14]. The Spanish law was used as a proxy for the industry's accommodation programmes. In July 2008 the Federal Constitutional Court concluded that although a complete ban would have been constitutional, "freedom of choice" and "mandatory designation" would provide an alternative to a $100 \%$ smokefree law - provided that the venues only have one room, are under $75 \mathrm{~m}^{2}$ in size, do not serve prepared food and are not accessible to minors [15]. The main characteristics of the interim solution proposed by the court included the key elements of the Spanish legislation (Ley 28/2005) and outlined the strategies of the accommodation programme operated by PM. The concept of separating smokers and non-smokers in larger venues ("Courtesy of Choice") and allowing smaller venues to choose if smoking is allowed ("Traditional Hospitality") reached constitutionality and was thereafter locked into 
the state laws of most German states. Only Bavaria became $100 \%$ smokefree after a referendum in 2010. In the Netherlands opponents of comprehensive smoking bans advocated for the "German model". In 2010 the Netherlands lifted an earlier ban for all bars, which did not exceed $70 \mathrm{~m}^{2}$ and were solely operated by the owners without employing additional staff. According to news reports this applied to over 3,000 of around 5,500 Dutch bars [16].

In contrast to most partial bans which introduced restrictions based on venue size, some regulations, such as the national laws in the Czech Republic, Bolivia, Mexico, and Nicaragua, and the Province of Buenos Aires in Argentina, allowed smoking rooms or smoking venues without size specifications, probably only following one of PM's accommodation concepts [7]. Since July 2010 it is enough to place a smoking or non-smoking sticker in any Czech restaurant or bar.

In the meantime some countries strengthened their legislation. In 2009, Mexico introduced strict regulations for the implementation of the national law, specifically to the provisions of the smoking rooms (e.g., negative pressure ventilation, sliding doors, etc.) making very difficult to have them in practice. Greece, which introduced a partial smoking ban in 2009, opted for a comprehensive smoking ban in 2010, but retained exceptions for airport lounges, as proposed in PM's " $A$ Smoking Place" concept [7].

The "Spanish model" was also used to challenge existing smoking bans, such as in Uruguay, where shortly after the introduction of a comprehensive national smokefree policy in 2006, a national tobacco company started an advertising campaign with the punchline "Spain and the freedom to choose" [17], implying that countries under that model would be more democratic and tolerant.

\section{Discussion}

The "Spanish model" has been used as a counter-model to effective smokefree legislation preventing and challenging the introduction of comprehensive smoking bans in several European and Latin American countries. The introduction of smoking bans in public places is often a gradual process, often reaching hospitality venues at a later stage. Most countries with partial smoking bans already had experiences PM's accommodation programmes and could thus have been more vulnerable to the "Spanish model". From recent policy analyses of the Spanish law and scientific studies on secondhand tobacco smoke exposure in hospitality venues we can conclude that separation by size is a failed approach and should not be introduced in any tobacco control legislation [18-25]. Following an extensive public debate and reports on positive developments in countries with comprehensive smoking bans, such as Ireland and the United Kingdom, and the scientific evaluations of the impact of the law, the Spanish government enacted new legislation in January 2011 amending its law and removing all exceptions for hospitality venues (new Ley 42/ 2010). Thus the "Spanish model" will no longer be that of a partial and weak ban, but a total one, as recommended by the FCTC [25].

What happened in Spain and elsewhere illustrates how partial bans, as promoted by the tobacco industry and parts of the hospitality sector, do not protect people against second-hand smoke. PM's strategy of using a common public relations agency for the management of the programs in Spain and Latin America demonstrates Spain's strategic position in the communication and dissemination of the programs across both regions [12]. The "new Spanish model" is an example of good practice for those countries aiming to go smoke-free. The Spanish experience should be used to counter the introduction of partial smoking bans across the globe and to support the global implementation of the FCTC. As the old "Spanish model" is dead, tobacco industry and their front groups are expected to use new terms, such as the "German model", to sell their accommodation programmes to policy makers and the media.

\section{Conclusion}

The Spanish experience not only demonstrates that partial bans often resemble tobacco industry strategies and are used to spread a failed approach on international level, but also that they are reversible. Researchers, advocates and policy makers should thus be aware of the origins of partial smoking bans, especially the socalled "Spanish model".

\section{Acknowledgements and funding}

The authors' work is supported by the following grants: Nick K. Schneider was funded by the German Cancer Research Center and the German Ministry of Health, Ernesto Sebrié was funded by the Flight Attendant Medical Research Institute (FAMRI) and Esteve Fernández was funded by Catalan Institute of Oncology, the Spanish Ministry of Health (PI081436 and RD06/0020/0089) and Catalan Ministry of Universities and Research (2009SGR192). None of the funding sources was involved in study design; data collection, analysis and interpretation; report writing; and decision to submit the paper for publication.

Submission declaration

Preliminary data on the "Spanish model" was presented by Nick K. Schneider and Dietmar Jazbinsek at the $14^{\text {th }}$ World Conference on Tobacco or Health in Mumbay, India in 2009 and by Nick K. Schneider at the $5^{\text {th }}$ European Conference on Tobacco or Health in Amsterdam, the Netherlands in 2011.

\section{Author details}

${ }^{1}$ German Cancer Research Center, Unit Cancer Prevention and WHO Collaborating Centre for Tobacco Control, Im Neuenheimer Feld 280, D69120 Heidelberg, Germany. ${ }^{2}$ Department of Health Behavior, Roswell Park Cancer Institute, Buffalo, New York, USA. ${ }^{3}$ Tobacco Control Unit, Cancer Prevention \& Control Programme, Institut Català d'Oncologia-IDIBELL, L'Hospitalet de Llobregat, Barcelona, Spain. ${ }^{4}$ Department of Clinical Sciences, 
School of Medicine, Campus de Bellvitge, Universitat de Barcelona, Barcelona, Spain

\section{Authors' contributions}

All three authors were involved in study design, data collection and manuscript development. NKS researched the tobacco industry documents on Spain and Europe and prepared the first manuscript. ES provided the data on Latin America and EF further documentation on Spain. All three authors commented all versions of the manuscript and approved the final version.

\section{Competing interests}

The authors declare that they have no competing interests.

Received: 28 June 2011 Accepted: 7 December 2011

Published: 7 December 2011

\section{References}

1. World Health Organization: WHO Framework Convention on Tobacco Control. Geneva; 2003.

2. Jefatura del Estado: Ley $28 / 2005$ de 26 de diciembre, de medidas sanitarias frente al tabaquismo y reguladora de venta, el suministro, el consumo y la publicidad de los productos de tabaco. BOE-A-2005-21261: Boletín Oficial del Estado, BOE 309 de 27/12/2005 2005, 42241-50.

3. Muggli ME, Lockhart NJ, Ebbert JO, Jimenez-Ruiz CA, Miranda JA, Hurt RD: Legislating tolerance: Spain's national public smoking law. Tob Control 2009.

4. Granero L, Villalbí JR, Gallego R: [Who is against prevention? A map of policy actors favoring smoking in Spain.]. Gac Sanit 2004, 18(5):374-9.

5. Hirschhorn N: The Tobacco Industry Documents: What They Are, What They Tell Use, and How to Search Them: A Practical Manual. Geneva, Switzerland: World Health Organization;[http://www.who.int/tobacco/ communications/TI_manual_content.pdf].

6. Goldberg H: International Accommodations Programs. 1999 [http://legacy. library.ucsf.edu/tid/trf19c00], Bates No. 2078585193/5216.

7. Morris Philip: Accommodation and Smoking Restrictions 1999 Plan 1998. [http://legacy.library.ucsf.edu/tid/opz37c00], Bates No. 2078743488/3505.

8. Fernández E, Galán I: Spain: partial airport bans unacceptable. Tob Control 2008, 17(3):148.

9. Goldberg H: Accommodation Programs - Where next? Philip Morris 2000 [http://legacy.library.ucsfedu/tid/fzz8ho0], Bates Nr. 2081001751/1757.

10. Philip Morris: Worldwide Strategy and Plan to Accommodate the Diverse Expectations Regarding Smoking in Strategic Public Settings and the Role of Ventilation. 1998 [http://legacy.library.ucsf.edu/tid/qkl27a00], Bates No. 2065232899/2915..

11. EURO-NEWSLETTER: EURO-NEWSLETTER 13 August 1999.[http://legacy. library.ucsf.edu/tid/trt63c00], Bates No. 2065344107/4109.

12. Areitio J, Braña J, Llorente JA: Consulting Services Agreement.Edited by: Philip Morris 1999 [http://legacy.library.ucsf.edu/tid/hkj11 h00], Bates No. 2070640585-0598.

13. Philip Morris International: Convivencia en Armonia - New Regional Agency. 1999 [http://legacy.library.ucsf.edu/tid/m×q59h00/pdf], p. Bates Nr. 2072593991/3993.

14. Imperial Tobacco/Reemtsma: Toleranz für Raucher. Wie machen's die anderen?: Reemtsma Cigarettenfabriken GmbH 2008 [http://www.reemtsma. com/index.php?id=206], Accessed: 13 October 2009.

15. German Constitutional Court: BVerfG, 1 BvR 3262/07 vom 30.7.2008, Absatz-Nr. (1 - 194). 2008

16. Belfast Telegraph: Smoking ban U-turn by Dutch government. 2010 [http://www.belfasttelegraph.co.uk/news/world-news/smoking-ban-uturn-bydutch-government-14995132.html], Accessed: 7 March 2011.

17. La industria tabacalera en el ojo de la tormenta [news]: El Espectador.com. Primer sitio multimedia de Uruguay. 2006 [http://www.espectador.com/ 1v4_contenido.php?m=\&id=74704\&ipag=1], Accessed: 23 September 2011].

18. German Cancer Research Center (Ed.): The "Spanish Model" of NonSmoker Protection in Hospitality Venues: A Failed Approach Deutsches Krebsforschungszentrum. 2008 [http://www.dkfz.de/de/tabakkontrolle/ download/Publikationen/AdWfP/AdWfP_The_spanish_Model_engl.pdf], Accessed: 15 February 2010.

19. German Cancer Research Center (Ed.): The failure of partial smoking bans in hospitality venues: The example of Germany and Spain. 2010, http://
www.dkfz.de/de/tabakkontrolle/download/Publikationen/AdWfP/

AdWfP_Failure_of_partial_smoking_bans.pdfAccessed: 10 December 2010.

20. Fernandez E, Fu M, Pascual JA, Lopez MJ, Perez-Rios M, Schiaffino A, Martinez-Sanchez JM, Ariza C, Salto E, Nebot M: Impact of the Spanish smoking law on exposure to second-hand smoke and respiratory health in hospitality workers: a cohort study. PLoS One 2009, 4(1):e4244..

21. Martinez-Sanchez JM, Fernandez E, Fu M, Perez-Rios M, Lopez MJ, Ariza C, Pascual JA, Schiaffino A, Perez-Ortuno R, Salto E, Nebot M: Impact of the Spanish smoking law in smoker hospitality workers. Nicotine Tob Res 2009, 11(9):1099-106.

22. Nebot M, Lopez MJ, Ariza C, Perez-Rios M, Fu M, Schiaffino A, Munoz G, Salto E, Fernandez E: Impact of the Spanish smoking law on exposure to secondhand smoke in offices and hospitality venues: before-and-after study. Environ Health Perspect 2009, 17(3):344-7.

23. Galán I, Mata N, Estrada C, Diez-Ganan L, Velazquez L, Zorrilla B, Gandarillas A, Ortiz H: Impact of the "Tobacco control law" on exposure to environmental tobacco smoke in Spain. BMC Public Health 2007, 7(147):224..

24. Nebot M, Fernández E: Tobacco Working Group of the Spanish Society of Epidemiology. [Impact assessment of the Spanish Tobacco Control Law]. Barcelona: Grupo de Trabajo en Epidemiología de la SEE, Ministerio de Sanidad y Política Social 2009 [http://www.seepidemiologia.es/monografia. pdf].

25. Fernandez E, Nebot M: Spain: Beyond the 'Spanish model' to a total ban. Tob Control 2011, 20:6-7.

Pre-publication history

The pre-publication history for this paper can be accessed here: http://www.biomedcentral.com/1471-2458/11/907/prepub

doi:10.1186/1471-2458-11-907

Cite this article as: Schneider et al: The so-called "Spanish model" Tobacco industry strategies and its impact in Europe and Latin America. BMC Public Health 2011 11:907.

\section{Submit your next manuscript to BioMed Central and take full advantage of:}

- Convenient online submission

- Thorough peer review

- No space constraints or color figure charges

- Immediate publication on acceptance

- Inclusion in PubMed, CAS, Scopus and Google Scholar

- Research which is freely available for redistribution

Submit your manuscript at www.biomedcentral.com/submit
Ciomed Central 